\title{
Foreign Direct Investment, Productivity, and Country Growth: An Overview
}

\author{
Silvio Contessi and Ariel Weinberger
}

\begin{abstract}
The authors review the empirical literature that studies the relationship between foreign direct investment, productivity, and growth using aggregate data and focus on two questions: Is there evidence of a positive relationship between foreign direct investment and national growth? And does the output of the "multinational sectors" exhibit higher labor productivity? The authors also briefly discuss how the microeconomic evidence and a number of aggregation and composition problems might help explain the ambiguous results in this literature. (JEL E32, F21, F32, F36)
\end{abstract}

Federal Reserve Bank of St. Louis Review, March/April 2009, 91(2), pp. 61-78.

"Today's policy literature is filled with extravagant claims about positive spillovers from FDI but the evidence is sobering." 1

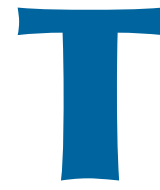

he notable growth of foreign direct investment (FDI) in the past 30 years continues to trigger conflicting reactions, in both industrial and emerging countries (Coughlin, 1992). In short, FDI is an investor's acquisition of "long-term influence" in the management of a firm in another country. (See the next section for a more complete definition.) In the developed world, countries that export capital and countries that import capital both raise concerns about FDI: The former are concerned that capital leaving their countries might be detrimental to domestic investment; the latter's politicians and workers fear foreign ownership of domestic firms. Emerging, transition, and developing countries (and at times local governments) usually welcome FDI, assuming that investment through this multinational activity will bring additional capital, managerial expertise, and technology.

1 From Rodrik (1999).
In economics, multinational activity (essentially foreign firms with U.S. production units and U.S. firms with foreign production units, described in more detail later) is also viewed as a positive contribution to the technological progress of the host economies. An established literature that dates back to Findlay (1978) develops models in which multinational firms own and transfer technology - which may not be available in the host country-that allows them to be more productive and profitable than firms that are not multinational in nature. Because such a transfer is assumed to contribute to the technical progress of the host economies, it is also assumed to contribute ultimately to their growth.

Rivera-Batiz and Rivera-Batiz (1991) develop a formal model that allows for increasing returns due to specialization as a result of FDI. Borensztein, De Gregorio, and Lee (1998) stress the interaction between FDI and investment in human capital. Helpman, Melitz, and Yeaple (2004) and Yeaple (2008) show that only the most productive firms in a country become multinationals, whereas progressively less productive firms enter progressively more attractive countries.

Silvio Contessi is an economist and Ariel Weinberger is a research analyst at the Federal Reserve Bank of St. Louis.

(C) 2009, The Federal Reserve Bank of St. Louis. The views expressed in this article are those of the author(s) and do not necessarily reflect the views of the Federal Reserve System, the Board of Governors, or the regional Federal Reserve Banks. Articles may be reprinted, reproduced, published, distributed, displayed, and transmitted in their entirety if copyright notice, author name(s), and full citation are included. Abstracts, synopses, and other derivative works may be made only with prior written permission of the Federal Reserve Bank of St. Louis. 


\section{Figure 1}

\section{National Regulatory Changes, 1992-2006}

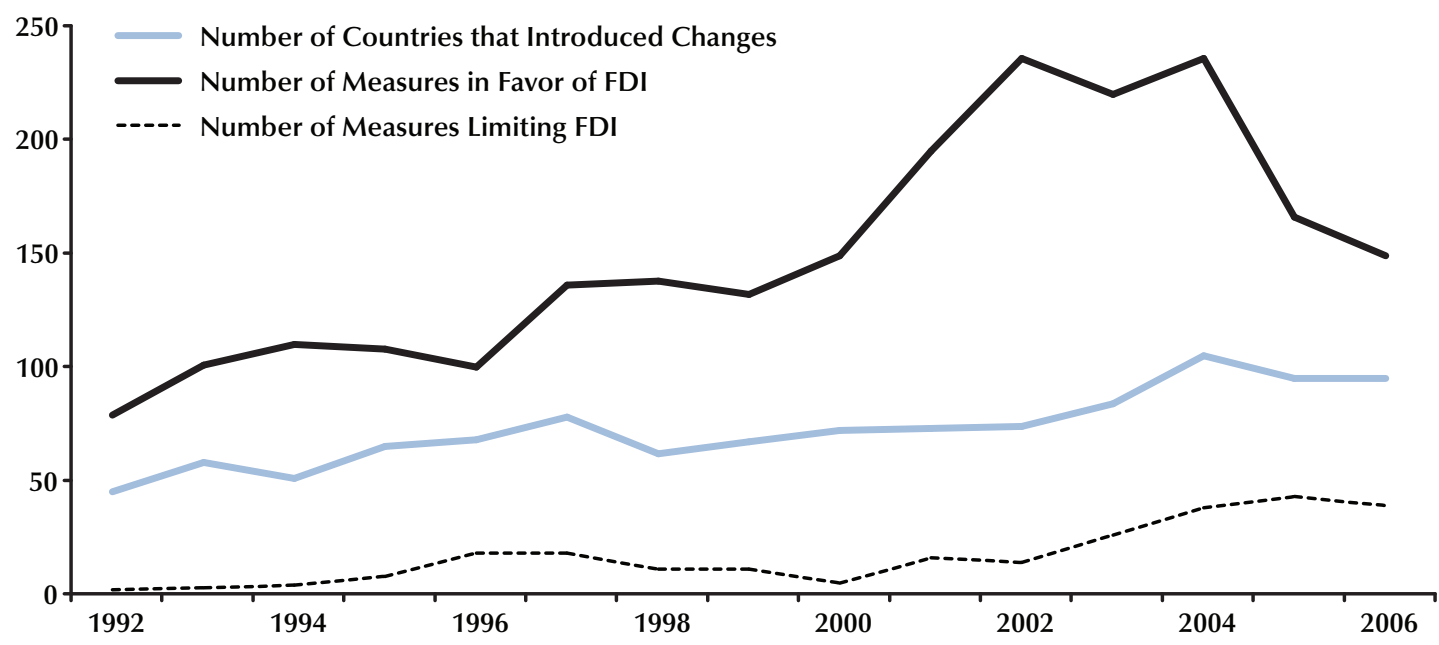

SOURCE: UNCTAD Database on National Laws and Regulations.

Some other studies highlight reasons why FDI may not accelerate growth: Aitken and Harrison (1999) argue that increased local competition caused by multinationals may crowd out domestic firms; Boyd and Smith (1992) show that FDI distorts resource allocation and slows growth when other distortions are present in the financial sector, prices, or trade. This would imply that FDI does not necessarily contribute to growth, and countries could be harming their economies with provisions that favor FDI.

As mentioned, overall FDI has increased in many countries. In Figure 1, we plot an index of the time series of the number of national regulatory changes between 1992 and 2006, which we obtained from various annual surveys on national laws and regulations. ${ }^{2}$ If we consider these series as proxies for the amount of intervention aimed at expanding and restricting FDI activities, the graph illustrates clearly the existence of a grow-

2 Specifically, we used various issues of The World Investment Report, an annual publication from the United Nations Commission on Trade and Development (UNCTAD) that focuses on FDI trends based partially on public data and partially on proprietary datasets and surveys and covers a different special topic every year: www.unctad.org. ing trend over the past 15 years of introduction of polices aimed at promoting FDI. Since 1992 at least 80 percent of regulatory changes have been favorable to FDI, particularly those in the 1990s. ${ }^{3}$ Furthermore, the absolute number of favorable changes has steadily increased since 1992, with some countries introducing more provisions and others that previously had no favorable provisions now passing legislation to encourage foreign investment.

This paper attempts to lay out the empirical evidence on each side. We review a number of macroeconomic studies that mostly fail to show convincing evidence that FDI contributes to growth. In particular, we organize our discussion around two questions: Is there evidence of a positive relationship between FDI and growth in macroeconomic data? And does the output of the

\footnotetext{
3 Specific examples of positive changes include the creation of new special economic zones in India, many of which offer tax holidays or other incentives, and variations in corporate taxes such as the change in Egypt's corporate tax from a base rate of 40 percent (32 percent for industrial and export activities) to a standard rate of 20 percent. Examples of negative changes include the restriction to a ceiling of 49 percent participation in Algerian state-owned oil and gas enterprises or the restriction to foreign participation in the Russian strategic sector, such as defense-related activities, aviation, and natural resources.
} 
multinational sector exhibit higher labor productivity? After explaining how to define and identify FDI in the next section, we discuss the evidence based on aggregate data and then the evidence regarding labor productivity. The final section offers a possible interpretation of this evidence.

\section{DEFINITIONS, MEASUREMENT, AND RELEVANCE}

\section{The Definition of FDI}

The most widely accepted definition of FDI is known as "the IMF/OECD benchmark definition" because it was provided by a joint workforce of these two international organizations with the objective of providing standards to national statistical offices for compiling FDI statistics. ${ }^{4}$ The gist of the definition is that FDI is an international venture in which an investor residing in the home economy acquires a long-term "influence" in the management of an affiliate firm in the host economy. According to the definition, the existence of such long-term influence should be assumed when voting shares or rights controlled by the multinational firm amount to at least 10 percent of total voting shares of rights of the foreign firm. ${ }^{5}$

Aggregate FDI flows are the sum of equity capital, reinvested earnings, and other direct investment capital; hence, aggregate FDI flows and stocks include all financial transfers aimed at financing of new investments, plus retained earnings of affiliates, internal loans, and financing of cross-border mergers and acquisitions. FDI flows can be observed from the perspective of the host economy, which records them as inward FDI along with other liabilities in the balance of payments, or from the perspective of the home economy,

\footnotetext{
4 The fourth revision of the OECD Benchmark Definition of Foreign Direct Investment (OECD, 2008) can be found here: www.oecd.org/ dataoecd/26/50/40193734.pdf. This collection of operational guidelines sets the world standard for FDI statistics, indicating to national statistical agencies the best practice to measure FDI activity. The benchmark definition was first published in 1983 based on a report by the OECD Group of Financial Statisticians, with revisions in 1990, 1992, and 2008.

5 Voting shares give the stockholder the right to vote on matters of corporate policymaking and on the appointment of the board of directors. If the equity share of control is 50 percent or more, the controlled firm is often defined as a subsidiary.
}

which records them as outward FDI, a category of assets. ${ }^{6}$

The sum of all direct capital owned by nonresidents in a given country $j$ in a certain time period $t$ constitutes the existing stock of FDI at that time. We will refer to the stock of foreign direct capital as $K_{j t}^{I}$. Hence, in each period $F D I_{j t}$ is the per-period increase in the stock of foreign direct capital, $F D I_{j t}=K_{j t}^{I}-K_{j t-1}^{I}$, in country $j$.

These measures can be sufficiently accurate in the short run. However, the value of the capital stock changes over longer periods, causing problems with the adjustment of its valuation. Over 20 years, the value of the stock of FDI at current prices may become three times as large as its historical value. For example, Ihrig and Marquez (2006) show that if one simply adds up net direct investment flows from 1982 to 2004, then the United States has net claims on foreigners of approximately $\$ 250$ billion; whereas, if one adjusts the values of assets and liabilities for inflation and changes in exchange rates (current cost), then net claims on foreigners in 2004 soar to almost $\$ 600$ billion. The difference between these two measures of the net direct investment position results from valuation adjustments over this time period. Another way to adjust the value is to calculate the net position at market value, a procedure that brings the net direct investment position to $\$ 500$ billion in 2004 .

Table 1 describes the composition of U.S. outward FDI, using stocks and flows in 2006. The data we use for this table do not capture the ultimate destination of flows that most statistical agencies try to report, but only the initial destination. Initial and final destinations might differ because multinational firms try to minimize the tax burden from multinational activity by exploiting the differences of fiscal regimes across countries. For example, the main FDI partners of the United States in 2006 include the Netherlands,

\footnotetext{
6 Three main types of private capital flows appear in the balance of payment accounts of a country: international debt, international portfolio flows, and FDI. FDI and portfolio investment are both a form of international equity investment, i.e., they represent shares of ownership of foreign firms, unlike private and public debt that is pledged to be returned at the end of the life of the international loan that generates it. The difference between FDI and portfolio equity, instead, is that the latter lacks the objective of influencing the management decisions of the controlled firm, and as such is generally more liquid and more short term.
} 


\section{Table 1}

\section{U.S. Outward FDI by Destination Country in 2006, Stocks and Flows}

\begin{tabular}{lcc} 
Country & $\begin{array}{c}\text { Stock of U.S. FDI holdings } \\
\text { in other countries (percent) }\end{array}$ & $\begin{array}{c}\text { U.S. outward FDI } \\
\text { by country (percent) }\end{array}$ \\
\hline U.K. & 15.29 & 6.88 \\
Netherlands & 11.43 & 18.42 \\
Canada & 9.37 & 3.67 \\
Bermuda & 5.48 & 8.53 \\
Switzerland & 4.69 & 5.07 \\
Japan & 3.76 & 4.56 \\
Luxembourg & 3.85 & 7.91 \\
Mexico & 3.39 & 3.96 \\
Germany & 3.92 & 2.42 \\
Other & 38.82 & 38.59 \\
Total & 100 & 100 \\
\hline
\end{tabular}

Bermuda, and Luxembourg, which offer particularly favorable fiscal regimes, although the final investment is likely to refer to an affiliate located in a third country.

Besides the problems with data reporting, the definitions used by statistical agencies may differ from the legal treatment of multinational firms in international treaties, such as the ones managed by the World Trade Organization (WTO) or NAFTA, that aim at reducing legal barriers to FDI. Although many efforts in this direction have been undertaken over the years, no encompassing multilateral treaty with the aim of setting standards for the liberalization of multinational activity exists, with two partial exceptions. The WTO treaties include (i) some specific measures aimed at the liberalization of FDI in the service sector in the General Agreement on Trade in Services (GATS) and (ii) some provisions meant to prevent members' actions aimed at restricting traderelated FDI in the Trade-Related Investment Measures (TRIMs) Agreement. No agreement exists to regulate FDI in the manufacturing sector.

\section{Measurement and Relevance}

Typically available macroeconomic time series for FDI include the nominal value of the flows in or out of a country (inward and outward) and stock values. Both measures have problems that sometimes undermine the cross-country comparability of the series, especially because statistical agencies of different countries may use different definitions of FDI. For example, in Estonia, the 10 percent benchmark for equity ownership suggested by the International Monetary Fund/ Organisation for Economic Co-operation and Development (IMF/OECD) definition of FDI has been applied only since the beginning of 2000 , whereas the previous threshold was 20 percent. Prior to 1997, Poland used a criterion of "effective voice in management" that might not have amounted to 10 percent or more ownership-a criterion they later adopted in compliance with international standards (IMF, 2003). In both cases, the series are clearly not comparable before and after the change in methodology, and large changes in their levels may either be a purely statistical artifact or have an economic basis to them.

A second problem with datasets available from international organizations, such as the ones available from the IMF, the World Bank, and the UNCTAD, is that they often have missing data points, particularly for developing countries.

A third issue with the use of aggregate data in studying FDI is that the records may not capture a part of the investment in the foreign project. The fact that multinational activities can be financed 


\section{Figure 2}

\section{Inward FDI Flows as a Percentage of Gross Fixed Capital Formation}
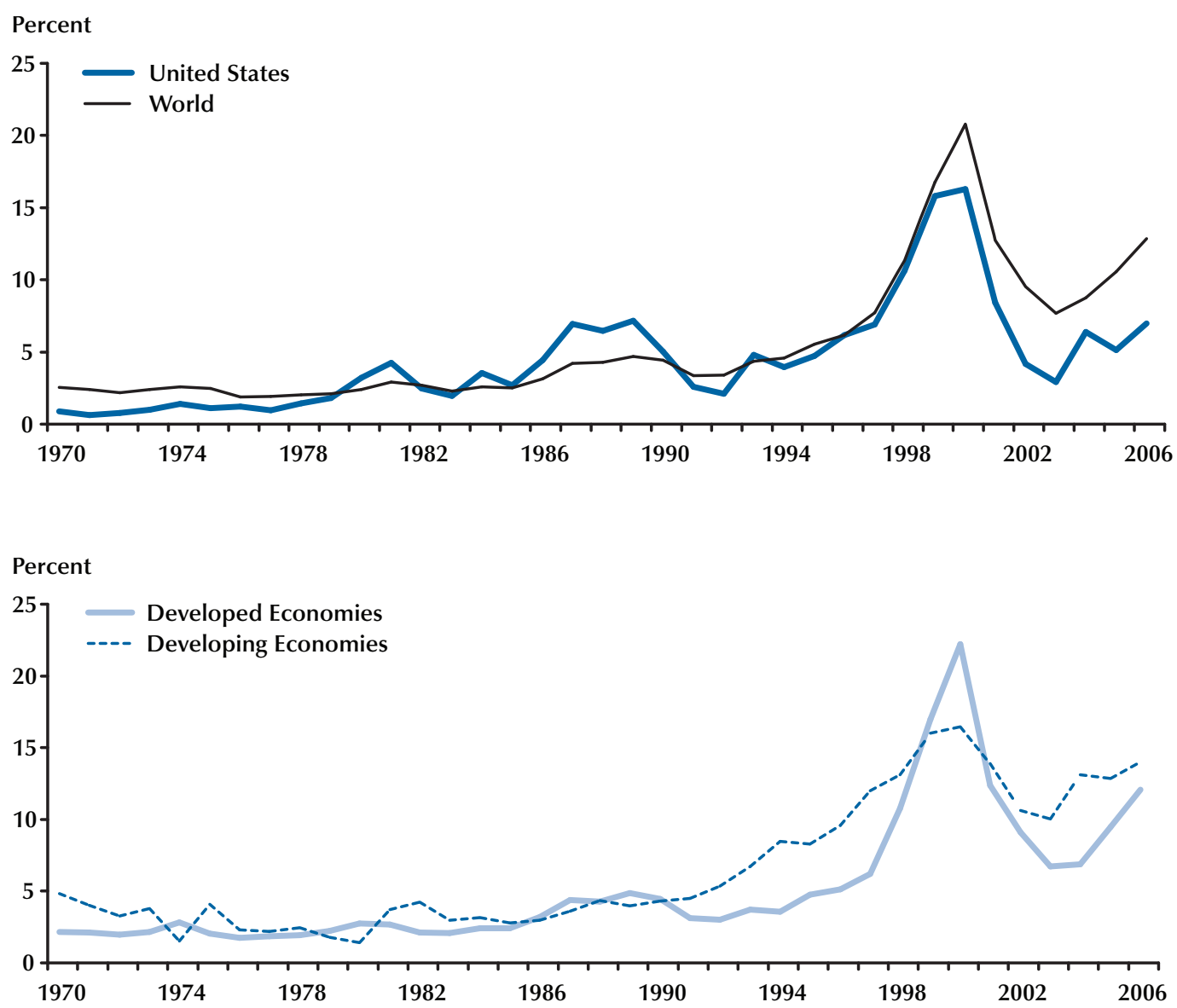

SOURCE: UNCTAD.

using local or foreign financial markets implies that measures of FDI flows and stock that capture only the foreign financing of the projects provide a potentially distorted measure of the extent of multinational activity across countries, as we discuss in the next paragraph. When foreign owners raise capital in the host country by issuing bonds or shares, no international capital flow is recorded in the balance of payment data of the source and the host country, and hence it does not show up in FDI statistics (Marin and Schnitzer, 2006). Therefore, using the flow of FDI might lead to incorrect inference, as part of the capital used to finance the multinational activity might be raised locally and hence not be recorded as an international capital flow in the balance of payments.

A common way to gauge the relevance of FDI is by comparing FDI with domestic investment. Figure 2 plots inward FDI flows as a percentage of gross fixed capital formation for developed and developing countries, as well as the world and the United States. The time series show clearly that these ratios were basically flat during the 1970s and part of the 1980s and subsequently started growing during the 1980s, eventually crossing the threshold of 5 percent.

Looking at groups of countries hides large variability in individual countries and regional 


\section{Figure 3}

\section{FDI Inflows in Developed (top) and Developing (bottom) Countries (percent)}
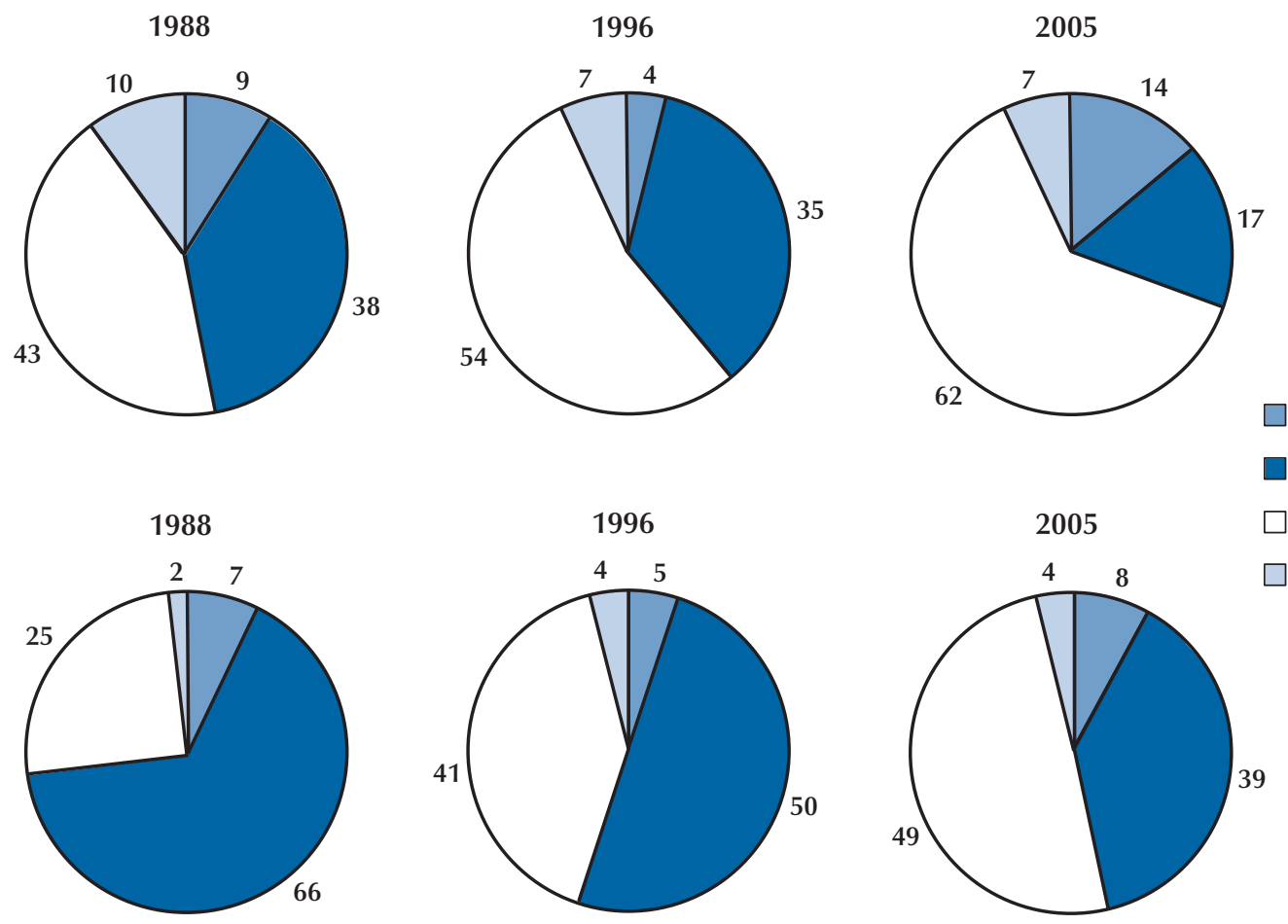

Primary

Manufacturing

Services

Unspecified experiences, even during these early years. Beginning in the mid-1980s, the ratio started to grow quite steeply and later accelerated in the mid1990 s to reach a peak at the end of the 1990s. ${ }^{7}$

After the large correction of equity prices of the late 1990s and the early 2000s recession, the flows of FDI as a share of gross fixed capital formation returned to the levels of the late 1980s. More recently, however, the slowdown reached a turning point and the ratio is back to a level between 5 and 10 percent for the world as a whole. It remains to be seen whether the 2008 credit contraction in OECD countries will mark another turning point. ${ }^{8}$

7 Part of the steep increase in the 1990s is due to the wave of crossborder mergers and acquisitions across OECD countries at the time.

8 Contessi, De Pace, and Francis (2008) show that industrial countries' outward and inward FDI is significantly procyclical, whereas emerging countries' inward FDI is significantly countercyclical.
The figures prompt two additional observations. First, the cyclical nature of FDI flows emerges quite clearly for the United States and developed countries, with at least three (long) boom-bust cycles with a first peak around 1980, a second peak around 1988, and a third peak in 2000-01. The second observation is that developing countries stand out because they experienced steady trend growth until 2000, rather than boombust cycles; moreover, in these countries the early 2000s correction is much less pronounced than in developed countries and certainly much less than in the United States. Inward flows to developing countries now make up a larger percentage of total inward investment when compared with developed countries.

Industrial and developing countries differ in other dimensions regarding FDI. In Figure 3 we compare the industry composition of FDI in indus- 
trial and emerging countries for three years, 1988, 1996, and 2005. Looking at both developed and developing countries one can see how the share of services in total flows has increased quite substantially-by almost 50 percent in fact-whereas the share of manufacturing has dropped to 50 percent of what it was in 1988 in industrial countries. This shift is likely due to the rise of the service sector; the elimination of many restrictions to foreign entry and ownership, particularly in the banking and telecommunications sector; and the commitments contained in the GATS agreement and other regional agreements. ${ }^{9}$ The pie charts in Figure 3 also reveal that the share of manufacturing FDI is consistently larger for developing countries than for developed countries, although less so as time goes by. Finally, this shift is also likely to be a response to comparative advantage and the emergence of vertical fragmentation of manufacturing production over the past decades.

\section{Do the Aggregate Data Show Evidence of a Positive Relationship Between FDI and Growth?}

Output is assumed to be produced according to the following production function:

$$
Y_{j}=Z_{j} f\left(K_{j}^{D}, K_{j}^{I}, L_{j}^{D}, L_{j}^{I}, M_{j}, \ldots\right),
$$

where final output of country $j$ in time $t$ (subscript omitted) is a function of a set of inputs, such as potentially different domestic and foreign capital $\left(K_{j}^{D}, K_{j}^{I}\right)$, domestic and possibly foreign labor $\left(L_{j}^{D}\right.$, $\left.L_{j}^{I}\right)$, intermediate inputs $\left(M_{j}\right)$, and other factors are combined using a technology $f(\cdot)$ common across firms and scaled by a total factor productivity parameter $Z_{j}$ to produce $Y_{j}$ units of real output.

Researchers who use aggregate data normally postulate that the aggregate production function is a Cobb-Douglas production function. Equation (1) then has the functional form

9 For example, many provisions aimed at completing the European Single Market or NAFTA's Chapter 11 contain specific FDI provisions that protect firms and individuals investing in Mexico, Canada, and the United States.

$$
Y_{j}=Z_{j}\left(K_{j}^{I}\right)^{\beta_{0}}\left(L_{j}^{I}\right)^{\varphi} \underbrace{\left(X_{j}\right)^{\gamma}}_{\left(K_{j}^{D}, L_{j}^{D}, M_{j}, \ldots\right)}
$$

and is transformed in logarithmic form and studied in first differences. The final regression estimate is

(3) $\dot{Y}_{j}=\alpha_{j}+\beta_{0} F D I_{j}+\beta_{1}\left(F D I_{j} \times x_{j}\right)+\gamma X_{j}+\varepsilon_{j}$,

where $\alpha_{j}$ is a constant, the matrix $\mathrm{X}_{\mathrm{j}}$ contains a number of non-FDI factors assumed to affect growth and varies greatly across studies, and the interaction term $\left(F D I_{j} \times X_{j}\right)$ takes care of possible interactions between FDI and other regressors, that is, other non-FDI factors that are assumed to affect growth and contained in $\mathrm{X}_{\mathrm{j}} \cdot{ }^{10}$ Researchers then test whether the estimated coefficient $\hat{\beta}_{0}$ is positive and significant in the regression.

The most common and somewhat natural way to measure growth in these studies is to use real per capita GDP growth. Measures of FDI may vary, but gross FDI inflows as a share of GDP, FDI inflows per capita, or multinational sales are common choices. FDI stocks are more troublesome not only because time series of flows date back to the 1970s at the earliest, making stocks series difficult to reconstruct for a sufficient number of countries, but especially because the values of firms and of the FDI stock change over time, introducing a substantive discrepancy between the originally recorded book value and the market value.

The matrix $\mathrm{X}_{\mathrm{j}}$ is a set of control variables and the specification leaves room for interaction terms between $F D I_{j}$ and one or multiple variables in $X_{j}$. The latter may include various measures of initial per capita income, average years of schooling of the working population, government size, inflation, openness to trade, black market premium, ${ }^{11}$ private credit, and so on. Loosely speaking, regression analysis including only the $F D I_{j}$ term usually reveals nonsignificant effects of $F D I_{j}$ alone through $\beta_{0}$, while regression analysis including an inter-

\footnotetext{
${ }^{10}$ Estimation techniques vary but usually range from ordinary least squares to dynamic panels.

${ }^{11}$ This is the percentage differential between the black market and the official exchange rate.
} 
action term with one of the variables in $X_{j}$ reveals a positive relationship.

Various panel and cross-sectional studies show the importance of different complementary variables. Balasubramanyam, Salisu, and Sapford (1996) use exports as a measure of openness to trade; Borensztein, De Gregorio, and Lee (1998) a proxy for human capital; and Alfaro et al. (2004) various proxies for financial development. ${ }^{12}$ They all find that $F D I_{j}$ has a positive impact only if an additional variable is interacted with it. Hence, the more the country is financially developed, open to trade, or endowed with human capital, the more FDI increases growth. Unfortunately, the most sophisticated in this group of studies, Carkovic and Levine (2005), demonstrates the lack of a robust positive correlation between FDI and growth once the temporal dimension of international data is exploited using panel data. ${ }^{13}$

There are at least two important caveats that might affect the reading of such results. The first more general caveat is common to cross-country growth regressions-that is, these studies are plagued by a multiplicity of issues of parameter heterogeneity, outliers, omitted variables, model uncertainty, measurement error, and endogeneity, as eloquently discussed in Rodrik (2005). Inference based on results that do not discuss the potential biases in these studies should be taken with a grain of salt. The second caveat was raised in Blonigen and Wang (2005), who argue that pooling rich and poor countries without distinguishing between levels of development (i.e., assuming the same $\beta_{0}$ for all countries and hence underestimating cross-country heterogeneity) leads to incorrect inference, an argument that squares nicely with the evidence discussed in the studies just cited. ${ }^{14}$ In particular, they show that

\footnotetext{
12 Borensztein, De Gregorio, and Lee (1998) average data over 10year periods, because annual flows might not have a discernible effect on growth over longer periods.

${ }^{13}$ Carkovic and Levine (2005) use 72 countries over the period 1960-95. They average data over non-overlapping, 5-year periods, so that there are seven observations per country (1961-65, 1966-70, and so on).

${ }^{14}$ Results in Contessi, De Pace, and Francis (2008), for example, echo this argument: They show that FDI inflows are clearly procyclical in developed countries but countercyclical in emerging countries and discuss how pooling all countries together would not reveal any pattern of cyclicality.
}

it is not the use of panel technique, but the pooling of countries with different levels of wealth, that makes the evidence of a positive relationship between FDI stocks and growth disappear. This is consistent with a previous study by Blomström, Lipsey, and Zejan (1994), which found no significant effect of foreign capital on economic growth of lower-income developing countries (as opposed to relatively richer developing countries), suggesting that the relationship may be positive for "sufficiently wealthy" countries.

In Figures 4 and 5, we plot the ratio of the inward FDI stock to GDP in 1990 and 2000 on the horizontal axis; on the vertical axis, we plot real GDP growth for the 1990-2000 period and for the 2000-05 period for the largest groups of countries for which these data are available in each of the periods. ${ }^{15}$ The scatter diagrams in the bottom part of each graph do not distinguish among different levels of development, whereas the top graphs do, in a way that isolates industrial countries (squares) and emerging and transition countries (triangles) from other less-developed countries (dots). Although we make no attempt at formal inference, we think that the picture alone suggests that the relationship between FDI and growth that we could infer from these relationships is quite different depending on the composition of the group of countries and the time period under scrutiny.

What do we learn from these studies? The positive relationship between FDI-whether flows, flows to GDP, or stocks-and growth emerges in macroeconomic data, when "some other factor" is present. However, the presence of FDI is likely to be affected by the presence of these factors, making the issue of endogeneity hard to resolve. If FDI has a positive impact on economic growth, it increases market size, and a larger market size attracts more FDI. Hence, FDI and growth are interdependent in a nontrivial way that needs to be somehow addressed in the econometric analysis, which has made two possible solutions available for similar problems: The first, the use of random-

\footnotetext{
${ }^{15}$ We obtained GDP growth data from the 2007 World Development Indicators of the World Bank and the stock of inward FDI to GDP from the "External Wealth of Nations-Mark II" dataset that has been publicly released by Lane and Milesi Feretti (2007).
} 


\section{Figure 4}

\section{FDI Stock-to-GDP Ratio and Real GDP Growth (1990-2000)}

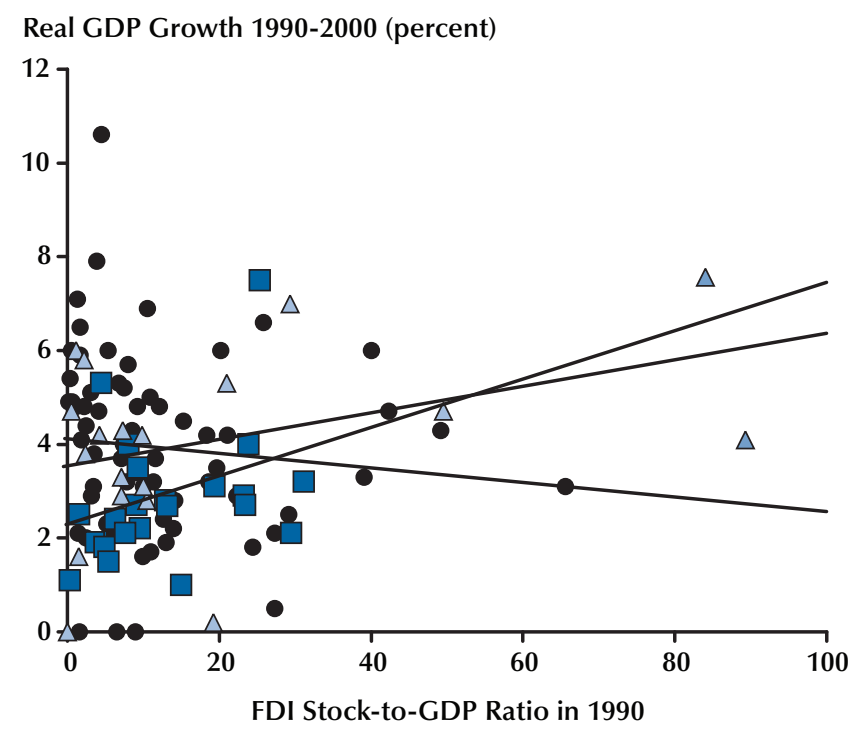

Real GDP Growth 1990-2000 (percent)

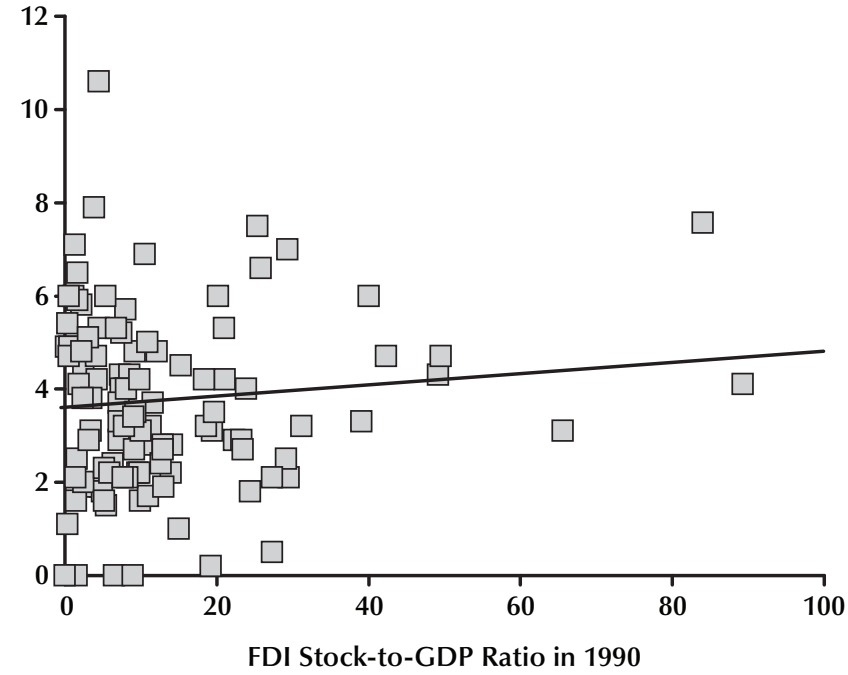

NOTE: In the top panel, triangles represent emerging economies, squares represent industrial countries, and dots represent all other countries. In the bottom panel, all countries are pooled together. The straight line is a linear trendline for each group.

SOURCE: 2007 World Development Indicators of the World Bank and "External Wealth of Nations-Mark II" dataset (Lane and Milesi Ferreti, 2007). 
Figure 5

FDI Stock-to-GDP Ratio and Real GDP Growth (2000-05)

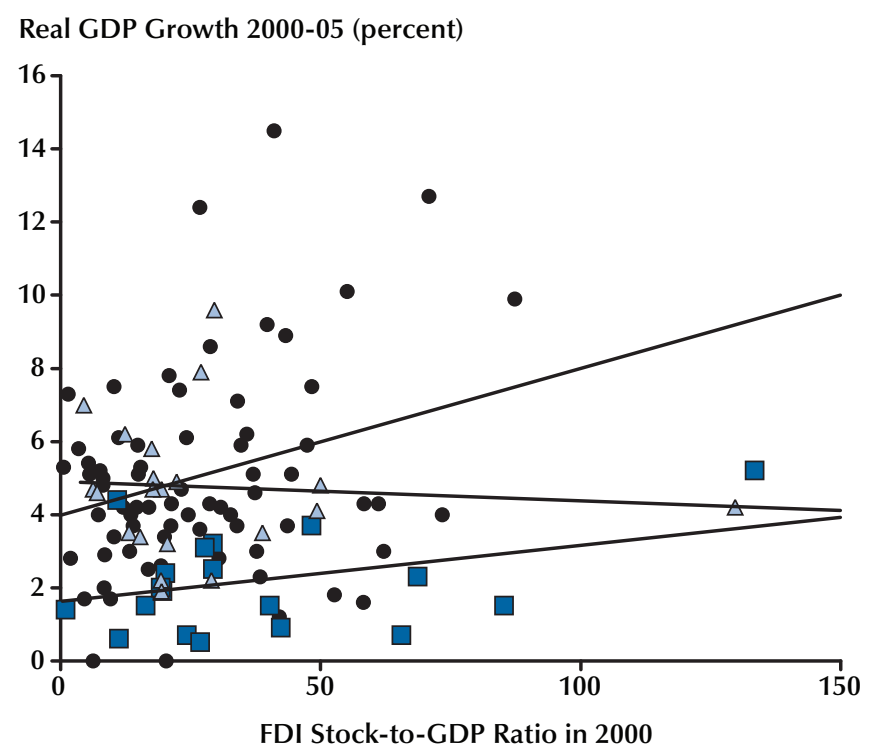

Real GDP Growth 2000-05 (percent)

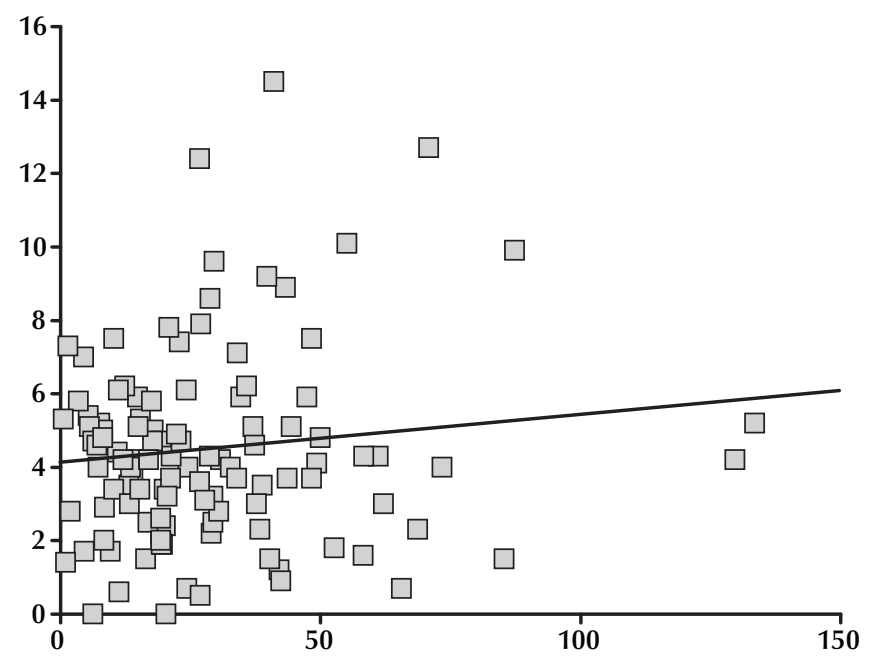

FDI Stock to GDP Ratio in 2000

NOTE: In the top panel, triangles represent emerging economies, squares represent industrial countries, and dots represent all other countries. In the bottom panel, all countries are pooled together. The straight line is a linear trendline for each group.

SOURCE: 2007 World Development Indicators of the World Bank and "External Wealth of Nations-Mark II" dataset (Lane and Milesi Ferreti, 2007). 
ized trials, is clearly impossible in growth regressions. However, Carkovic and Levine (2005) argue that the second, the use of more sophisticated panel techniques, can substantially alleviate the problem of endogeneity. ${ }^{16}$

In the discussion of Carkovic and Levine (2005) and Blonigen and Wang (2005), Melitz (2005) puts forward the possibility that certain types of FDI ventures known in the literature as export platform FDI may have a potentially larger effect on growth. Hence, export-oriented countries may benefit more from FDI than importsubstituting countries, an idea originally discussed in Bhagwati (1988) and tested explicitly in Balasubramanyam, Salisu, and Sapford (1996). For example, the Volkswagen automobile plant in Puebla, Mexico, is the only assembly unit of this multinational in North America but meets the demands of the three NAFTA countries. Although the motivations of this venture are both cost saving through lower input costs and access to the sizeable North American consumer markets, the factory benefits the Mexican economy more than it would if its production were sold only in Mexico.

A part of the literature that uses aggregate data has focused on regional, rather than county, growth. The methods used are very similar to studies we just described: Authors attempt to disentangle the various variables affecting productivity growth to single out the individual effect that can be attributed to foreign investment. Although cross-country models attempt to measure the "average" effects that FDI has on countrywide economic outcomes as a whole, they cannot measure how certain subnational units might be affected. Regional growth studies deal with very specialized locales and can focus on the effects of foreign investment in the particular community where multinational firms establish their operations. In particular, although evidence suggests foreign investment increases wages and growth, it is unclear whether certain areas benefit suffi-

\footnotetext{
${ }^{16}$ Carkovic and Levine (2005) argue that instrumental variables and the use of dynamic panels estimated by generalized method of moments can help in this context. Given the nontechnical level of our article, we invite the interested reader to consult this article for further details.
}

ciently to outweigh the costs incurred, particularly in terms of incentives to locate in the area. Figlio and Blonigen (2000) and Ford, Rork, and Elmslie (2008) find that foreign investment has more positive effects than domestic investment, but with substantial costs to local communities in terms of reduction of budget expenditures.

Foreign investment's worst effect appears to be the crowding out of domestic investment. Figlio and Blonigen (2000) use a detailed countylevel panel dataset from South Carolina to compare foreign manufacturing firms with domestic manufacturing firms using share of employment. They estimate the following model:

$$
w_{j k t}=\alpha_{0} L_{j k t}+\alpha_{1} 1_{j k t}^{I}+\delta \gamma_{k t}+\delta_{j}
$$

where $j$ and $t$ are, respectively, counties and years for each industry $k$. In the model, $w_{j k t}$ is the average annual wage, $L_{j k t}$ is total manufacturing employment, $l_{j k t}^{I}$ is the level of employees in foreign-owned establishments, and $\gamma_{k t}$ and $\delta_{j}$ are unobserved county-specific differences in wages and timevarying effects, respectively. ${ }^{17}$ The authors also estimate a similar model that replaces wages with budget expenditures. They find that a marginal new foreign manufacturing job has seven times the effect on wages as does a new domestic job, but also that the new foreign job is associated with twelve times the revenue reduction and eight times the expenditure reduction. Therefore, the findings suggest that although new foreign investment can have a positive effect on wages, the welfare effect on the local community will depend on the magnitude of benefits versus the costs of investment in the community; and the costs can be nontrivial.

Finally, a study by Ford, Rork, and Elmslie (2008), similar to the panel studies described above, adds an interaction term of FDI with human capital and finds that FDI has a greater impact on growth per capita than domestic investment in U.S. states, conditional on a minimum human capital threshold, exactly as occurs in studies that use country data. This implies that FDI is posi-

\footnotetext{
17 Notice that the total manufacturing employment measure, however, does not exclude the level of employees in foreign-owned "greenfield" plants, a feature that might introduce a bias in the estimates.
} 
tively related to states' growth only when a sufficient level of human capital is present and that only states with a comparatively well-trained workforce can take advantage of the presence of foreign technology and should try to attract FDI.

\section{DOES THE OUTPUT OF THE MULTINATIONAL SECTOR EXHIBIT HIGHER LABOR PRODUCTIVITY?}

There is important information contained in aggregate data about FDI and labor productivity, as studied in Corrado, Lengermann, and Slifman (forthcoming) for the United States and Criscuolo (2005) for a group of OECD countries.

Corrado, Lengermann, and Slifman (forthcoming) focus on labor productivity in the United States. The United States is a particularly interesting country in that productivity has increased at a particularly high average annual rate of 1.84 percent between 1977 and 2006, faster than in most other industrial countries, at least since 1995. Moreover, the United States is both a major recipient of FDI from abroad and an especially major source of FDI for the rest of the world. The authors separate U.S. gross domestic product and productivity growth into that produced by exclusively domestic firms and that produced by the so-called multinational sector (i.e., the "industry" composed of foreign firms with U.S. production units and U.S. firms with foreign production units-not only foreign firms in the United States). Labor productivity estimates are then calculated by sector: In each year, productivity levels are defined as real value added per total hours worked of all persons. Private multinational nonfarm, nonfinancial firms (again, not just foreign producers in the United States) contribute only 40 percent of the output of nonfinancial corporations but more than 75 percent of the increase in labor productivity between 1977 and 2000. Moreover, all of this new productivity in nonfinancial corporate sectors in the late 1990s can be traced back to multinationals (Figure 6 and Table 2).

Does the evidence for the United States carry over to a broader set of industrial countries? Criscuolo (2005) evaluates the direct contribution of the affiliates of foreign multinational firms to labor productivity for a large set of OECD host countries and shows that the productivity advantage of affiliates of multinational firms varies greatly across countries in both the manufacturing and service sectors. ${ }^{18}$ In the United States, France, and Sweden, foreign affiliates have approximately the same level of measured labor productivity as domestic firms. In Spain, Hungary, and the United Kingdom, foreign affiliates are twice as productive and this advantage appears to be markedly larger in low-tech sectors, such as food products, beverages, tobacco, textile and garment, leather, and footwear. Two possible explanations for the lack of affiliates' advantage in the United States, France, and Sweden are that domestic firms in these countries are at the technological frontier in many sectors and that domestic firms' productivity might have increased as a response to early trade openness and foreign competition. Hence, the data might be revealing that openness to competition induces survival and development of more-productive firms that in turn are more likely to become multinationals and contribute to their home country's productivity growth-as the Corrado, Lengermann, and Slifman (forthcoming) study would suggest. In Criscuolo (2005), however, the contribution to total productivity growth is quite heterogeneous, ranging from 32 percent in the United States to 42 percent in Finland, 164 percent in the Czech Republic, and an astonishing 251 percent in Norway (the highest). ${ }^{19}$ Her study is consistent with Corrado, Lengermann, and Slifman (forthcoming) because they define the multinational sector as the sum of foreign affiliates in the United States and U.S. firms that are multinational and control affiliates in other countries.

Interestingly, Criscuolo (2005) also shows how in a given time period, for example one year, the contribution to labor productivity growth can be decomposed into two components: a within effect,

\footnotetext{
${ }^{18}$ The sources of data are three OECD maintained datasets: the STAN productivity database, the AFA (Activity of Foreign Affiliates) database, and the FATS (Foreign Affiliates' Trade in Services) statistics. The time period considered is 1995-2001.

${ }^{19}$ Contributions larger than 100 percent are explained by a steep increase in the presence of affiliates with a higher labor productivity or by negative labor productivity growth of domestic firms, as in the United Kingdom.
} 


\section{Figure 6}

\section{Growth of U.S. Labor Productivity}

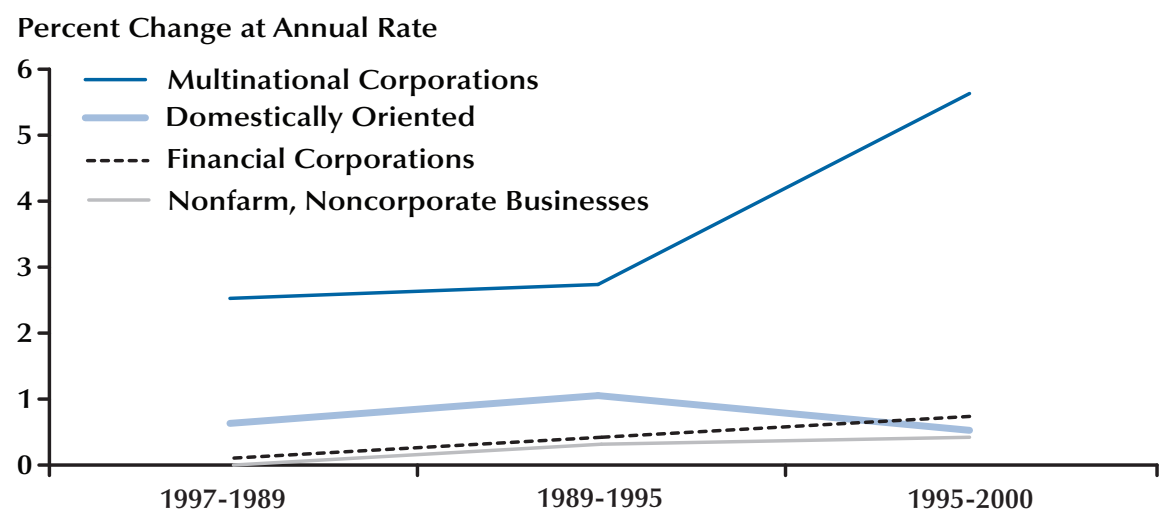

SOURCE: Corrado, Lengermann, and Slifman (forthcoming).

attributed to existing multinationals located in a country, and a between effect, attributed to the increase in the share of the employment of multinational affiliates. In her article, the within component drives the results in the United States, Hungary, and the Netherlands, while in all other countries the between component is the main contributor. The author also shows that the within effect is stronger in high-tech sectors, which are presumably information technology-intensive, which is a result that is consistent with the findings in microdata, as in Bloom, Sadun, and Van Reenen (2007).

Finally, a different dimension of disaggregation, industry composition, might be important in understanding the FDI contribution to growth. Based on an industry-level analysis, Fillat Castejón and Wörz (2006) argue that disaggregating flows by industry conveys important information because industrial specialization and composition are different across countries and this may affect the ability of a country as a whole to take advantage of the multinationals' technology. Even at the industry level, and in line with previous studies, Fillat Castejón and Wörz (2006) find that an additional factor needs to be included in the cross-country or cross-industry regression. Their analysis confirms previous analysis in terms of

\section{Table 2}

Composite of U.S. GDP, 1997 and 2002 (\%)

\begin{tabular}{lcr} 
& $\mathbf{1 9 7 7}$ & $\mathbf{2 0 0 2}$ \\
\hline Multinational corporations & 25.5 & 26.2 \\
Domestically oriented & 45 & 39.3 \\
Financial corporations & 4.6 & 9.2 \\
Noncorporate businesses & 25 & 25.3
\end{tabular}

SOURCE: Corrado, Lengermann, and Slifman (forthcoming).

requiring "other factors"-namely, export orientation and domestic investment in this case-to find a positive relationship between FDI and growth in the data.

\section{WHAT DO AGGREGATE DATA HIDE?}

As Criscuolo (2005) shows, disaggregating the data helps illuminate the effects of multinational affiliates' activity on productivity and ultimately on growth.

Imagine dividing the population of firms in the host economy into a foreign multinational component (indexed by $I$ ) and a purely domestic 
component (indexed by $D$ ). Then total final output, $Y_{j}$, could be also reinterpreted as the sum of two components produced by domestic and foreign firms, $Y_{j}=Y_{j}^{D}+Y_{j}^{I}$. In each time period a total of $N_{j}^{D}$ domestic firms and $N_{j}^{I}$ affiliates of multinational firms produce and sell locally $Y_{j}^{D}$ and $Y_{j}^{I}$, and perhaps a share of these firms sells abroad as exporters. (In this context, the distinction can be neglected without loss of generality.) One of the issues with estimation of aggregate data models like equation (3) is that variables referring to foreign firms are not excluded from the aggregate and the dependent variable is the growth rate of total output. If we distinguish domestic from foreign firms and the real output they produce, then we are really considering two production functions and observing total output as the sum of the output of the domestic firms and the multinational firms:

$$
\begin{gathered}
Y_{j}=Y_{j}^{D}+Y_{j}^{I} \\
Y_{j}^{D}=Z_{j}^{D} f\left(K_{j}^{D}, X_{j}^{D}\right) \\
Y_{j}^{I}=Z_{j}^{I} f\left(K_{j}^{I}, X_{j}^{I}\right) .
\end{gathered}
$$

There are at least two dimensions along which microeconomic heterogeneity affects econometric analyses that use aggregate data.

First, there may be important aggregation effects that might mirror microeconomic heterogeneity in terms of directly measurable productivity advantages $\left(Z_{j}^{I}>Z_{j}^{D}\right)$. If there is a large heterogeneity of multinational firms across countries and over time, and cross-country or panel studies that do not account for it, the average impact of FDI on growth may have little economic meaning. Contessi (2009a,b) discusses how thinking of multinational firms as heterogeneous agents in the sense of Ghironi and Melitz (2005) may help to reconcile the evidence on superior productivity leadership with the aggregate evidence discussed in this paper. Ghironi and Melitz (2005) assume that a firm's labor productivity is the product of an idiosyncratic time-invariant productivity level and a time-varying aggregate productivity level that is common across all firms in the economy. ${ }^{20}$ The idiosyncratic productivity level can be interpreted as the management's ability to appropriate and scale up (or down) the existing technology available to all firms. If one assumes the existence of fixed costs to export (as in Ghironi and Melitz, 2005) or to engage in multinational production (as in Contessi, 2009b), then some firms will export, some firms will be multinational, and the participation of firms in international markets evolves over time with entry and exit dynamics.

If firms incur a fixed cost to become multinationals, and either this cost decreases over time because of FDI liberalization or the attractiveness of foreign markets increases due to their growth, then entrants sort according to their own productivity. The most productive firms become multinationals earlier, while firms that are relatively less productive enter host economies later, a fact documented by Yeaple (2008) using firm-level data for U.S. multinationals. Specifically, Yeaple (2008) finds that a 10 percent increase in a host country's GDP is associated with a 5.4 percent increase in the number of U.S. firms owning an affiliate there, but also with a 1.4 percent decrease in the average productivity of the entrants. Entry of relatively less-productive firms then reduces the average productivity of the "multinational sector" in the host economy, exactly while the stock of FDI increases. Hence, while we expect countries with larger stocks of FDI to grow faster, the contribution of multinational firms to the host countries' productivity level, and growth, decreases.

Second, there may be relevant positive externalities (spillovers) that regressions based on aggregate data are likely to miss. The presence of spillovers implies that the mere presence of a foreign firm increases the productivity of domestic firms-or, in our discussion, $\partial Z_{j}^{D} / \partial N_{t}^{I}>0$. There are at least three groups of intra-industry spillovers. Javorcik (2008) contains an updated survey of the literature on spillovers from FDI and an interesting discussion of the reasons why their presence is difficult to measure and appears to vary greatly across countries.

\footnotetext{
${ }^{20}$ By idiosyncratic productivity, we mean firm-specific labor or total factor productivity that is not common to other firms.
} 
The demonstration effect is the first type of positive agglomeration externality: Although foreign firms have a strong incentive to protect their firm-specific product or process knowledge, domestic companies can still observe their practices to some extent and learn about new technology, marketing techniques, and product development. Second, domestic firms may hire workers who were employed, and hence trained, by multinationals in the past; in this case, spillovers occur through workers' mobility. Third, intra-industry spillovers may also occur through the so-called competition effect: Domestic firms must increase their productivity to compete with the foreign firms and survive their competition, while nonprofitable firms are likely eliminated from the market.

There are various ways in which the presence of spillovers from FDI may alter our reading of growth regressions that study FDI, as discussed in Hale and Long (forthcoming). On the one hand, if aggregate output measurements include the output of both the domestic sector and the output of foreign multinationals in the country, then the impact of FDI will always be positive $\left(\hat{\beta}_{0}>0\right)$, even if domestic productivity is not affected by the foreign presence, just because the output measurement already incorporates the multinational output growth that will always positively correlate to multinational presence. Hence, one would want to use only domestic output as a dependent variable.

On the other hand, estimating the presence of spillovers using data that focus on domestic variables is conducive to a second type of bias. A large part of recorded FDI consists of acquisition, rather than new establishments. Hence, a selection bias problem, called cherry-picking in the literature, has to be dealt with in formal analyses. If acquired affiliates are picked from the upper tail of the productivity distribution (firms with high productivity ex ante), the postacquisition distribution is truncated from above. This means that the larger the number of acquisitions, the lower the share of domestically owned firms with relatively lower productivity left in the population of "domestic" firms. If one estimates a regression such as the one in equation
(3), then the effect of $F D I_{j}$ will be negative $\left(\hat{\beta}_{0}<0\right)$. Therefore, the researcher should estimate a model with sample selection in the tradition of Heckman (1979) using firm- or plant-level data.

These issues are likely to be at least in part responsible for the lack of evidence of a relationship between FDI and growth that we discussed earlier in this article.

\section{CONCLUSION}

The contributions that multinational firms make toward economic growth of the host economies have been studied extensively, but little consensus has emerged as to whether FDI is boon or bane for a country as a whole. Quite simply, the evidence is as mixed now as it was when Rodrik (1999) wrote the line quoted at the beginning of this article. Lacking unambiguous empirical evidence, it is difficult to formulate solid expectations on how proposed FDI policies will affect the entry of foreign firms. Current empirical evidence provides little guidance as to whether one should support or oppose policies. As we have discussed in this article, studies that use a growth regression approach and aggregate data are not likely to help researchers sort out the growth effect of FDI because of methodological problems and huge heterogeneity hidden by the data. The prior 10 years of research have confirmed that the (aggregate) evidence is still sobering.

However, a large body of empirical research that uses firm- and plant-level data has documented that multinational firms and their affiliates (compared with domestic firms) are larger, are more capital intensive, make more abundant use of skilled workers, invest more in physical and intangible capital, and pay higher wages (Barba Navaretti and Venables, 2004). Because the evidence based on microdata shows that firms investing and producing in foreign countries have superior productivity at home, foreign affiliates should also enjoy a productivity advantage compared with local firms in the host economy. Indeed, we have discussed some of the evidence that reveals such an effect in aggregated data.

Recent developments in the use of microdata to study aggregate productivity such as the ones 
proposed by Petrin and Levinsohn (2005) might prove to be key in overcoming the methodological difficulties and the problems arising with the use of aggregate data; ultimately, these developments may increase our understanding of this relationship between FDI, productivity, and growth.

\section{REFERENCES}

Aitken, Brian and Harrison, Ann. "Do Domestic Firms Benefit from Direct Foreign Investment? Evidence from Venezuela." American Economic Review, June 1999, 89(3), pp. 605-18.

Alfaro, Laura; Chanda, Areendam; Kalemli-Ozcan, Sebnem and Sayek, Selin. "FDI and Economic Growth: The Role of Local Financial Markets." Journal of International Economics, October 2004, 64, pp. 89-112.

Balasubramanyam, V.N.; Salisu, M. and Sapford, David. "Foreign Direct Investment and Growth in EP and IS Countries." Economic Journal, January 1996, 106(434), pp. 92-105.

Barba Navaretti, Giorgio and Venables, Anthony. Multinational Firms in the World Economy. Princeton, NJ: Princeton University Press, 2004.

Bhagwati, J.N. "Protectionism," in The Ohlin Lectures. Cambridge, MA: MIT Press, 1988.

Blomström, Magnus; Lipsey, Robert E. and Zejan, Mario. "What Explains Developing Country Growth?” NBER Working Paper No. 4132, National Bureau of Economic Research, 1994.

Blonigen, Bruce A. and Wang, Miao. "Inappropriate Pooling of Wealthy and Poor Countries in Empirical FDI Studies,” in Theodore H. Moran, Edward D. Graham, and Magnus Blomström, eds., Does Foreign Direct Investment Promote Development? Washington, DC: Institute for International Economics, 2005, pp. 221-44.

Bloom, Nicholas; Sadun, Raffaella and Van Reenen, John. "Americans Do I.T. Better: US Multinationals and the Productivity Miracle." NBER Working
Paper No. 13085, National Bureau of Economic Research, 2007.

Borensztein, Eduardo; De Gregorio, Jose and Lee, Jong-Wha. "How Does Foreign Direct Investment Affect Economic Growth?” Journal of International Economics, June 1998, 45(1), pp. 115-35.

Boyd, John H. and Smith, Bruce D. "Intermediation and the Equilibrium Allocation of Investment Capital: Implications for Economic Development." Journal of Monetary Economics, December 1992, 30(3), pp. 409-32.

Carkovic, Maria and Levine, Ross. "Does Foreign Direct Investment Accelerate Economic Growth?" in Theodore H. Moran, Edward D. Graham, and Magnus Blomström, eds., Does Foreign Direct Investment Promote Development? Washington, DC: Institute for International Economics, 2005, pp. 195-220.

Contessi, Silvio. "FDI, Productivity, and Growth: Can We Reconcile Microeconomic and Aggregate Evidence?" Unpublished manuscript, 2009a.

Contessi, Silvio. "What Happens When WalMart Comes to Your Country? Multinational Firms' Entry, Productivity, and Inefficiency." Unpublished manuscript, 2009b.

Contessi, Silvio; De Pace, Pierangelo and Francis, Johanna. "The Cyclical Properties of Disaggregated Capital Flows." Working Paper No. 2008-041, Federal Reserve Bank of St. Louis, November 2008; http://research.stlouisfed.org/wp2008/2008-041.pdf.

Corrado, Carol; Lengermann, Paul and Slifman, Larry. "The Contribution of MNCs to US Productivity Growth 1977-2000," in M. Reinsdorf and M. Slaughter, eds., International Flows of Invisibles: Trade in Services and Intangibles in the Era of Globalization. Chicago: University of Chicago Press and NBER, forthcoming.

Coughlin, Cletus. "Foreign-Owned Companies in the United States: Malign or Benign?" Federal Reserve Bank of St. Louis Review, May/June 1992, 74(3), pp. 17-31. (Reprinted in Robert W. Kolb, ed., International Finance Reader. Boulder, CO: Kolb Publishing, 1993.) 
Criscuolo, Chiara. "Foreign Affiliates in OECD Economies: Presence, Performance, and Contribution to Host Countries." OECD Economic Studies, 2005, 41(2), pp. 109-39.

Figlio, David and Blonigen, Bruce. "The Effects of Direct Foreign Investment on Local Communities." Journal of Urban Economics, September 2000, 48(2), pp. 338-63.

Fillat Castejón, Carmen and Wörz, Julia. "Good or Bad? The Influence of FDI on Output Growth: An Industry-level Analysis." WIIW Working Paper No. 38, Vienna Institute for International Economic Studies, 2006.

Findlay, Ronald. "Relative Backwardness, Direct Foreign Investment, and the Transfer of Technology: A Simple Dynamic Model." Quarterly Journal of Economics, February 1978, 92(1), pp. 1-16.

Ford, Timothy; Rork, Jonathan and Elmslie, Bruce. "Foreign Direct Investment, Economic Growth, and the Human Capital Threshold: Evidence from US States." Review of International Economics, February 2008, 16(1), pp. 96-113.

Ghironi, Fabio and Melitz, Marc. "International Trade and Macroeconomic Dynamics with Heterogeneous Firms." Quarterly Journal of Economics, August 2005, 120, pp. 865-915.

Hale, Galina and Long, Cheryl. "Are There Productivity Spillovers from Foreign Direct Investment in China?" Pacific Economic Review, forthcoming.

Heckman, James J. "Sample Selection Bias as a Specification Error.” Econometrica, January 1979, 47(1), pp. 153-61.

Helpman, Elhanan; Melitz, Marc J. and Yeaple, Stephen R. "Export Versus FDI with Heterogeneous Firms." American Economic Review, March 2004, 94(1), pp. 300-16.

Ihrig, Jane and Marquez, Jaime. "Modeling Direct Investment Valuation Adjustments and Estimating Quarterly.” International Finance Working Paper No. 857, Board of Governors of the Federal Reserve System, 2006.
International Monetary Fund. "Direct Investment Methodology: Latest SIMSDI Metadata: Individual Country." 2003; www.imf.org/external/np/sta/di/ country.asp.

Javorcik, Beata S. "Can Survey Evidence Shed Light on Spillovers from Foreign Direct Investment?" World Bank Research Observer, 2008, 23(2), pp. 139-59.

Lane, Philip and Milesi Ferretti, Gian-Maria. "The External Wealth of Nations Mark II: Revised and Extended Estimates of Foreign Assets and Liabilities." Journal of International Economics, November 2007, 73(2), pp. 223-50.

Marin, Dalia and Schnitzer, Monika. "When Is FDI a Capital Flow?” CEPR Discussion Paper No. 5755, Centre for Economic Policy Research, July 2006.

Melitz, Marc J. "Comment," in Theodore H. Moran, Edward D. Graham, and Magnus Blomström, eds., Does Foreign Direct Investment Promote Development? Washington, DC: Institute for International Economics, 2005.

OECD. OECD Benchmark Definition of Foreign Direct Investment. Fourth Edition. Paris: OECD, 2008.

Petrin, Amil and Levinsohn, James. "Measuring Aggregate Productivity Growth Using Plant-Level Data.” NBER Working Paper No. 11887, National Bureau of Economic Research, 2005.

Rivera-Batiz, Francisco and Rivera-Batiz, Luis. "The Effects of Direct Foreign Investment in the Presence of Increasing Returns Due to Specialization.” Journal of Development Economics, November 1991, 34(1-2), pp. 287-307.

Rodrik, Dani. The New Global Economy and Developing Countries: Making Openness Work (Policy Essay 24). Baltimore, MD: Johns Hopkins University Press, 1999.

Rodrik, Dani. "Why We Learn Nothing from Regressing Economic Growth on Policies.” Unpublished manuscript, Harvard University, March 2005. 


\section{Contessi and Weinberger}

Yeaple, Stephen. "Firm Heterogeneity and the Structure of U.S. Multinational Activity: An Empirical

Analysis.” NBER Working Paper No. 14072, National

Bureau of Economic Research, 2008. 